\title{
Vastakkainasettelut ovat ikuisia?
}

\section{Kukku Melkas ja Olli Löytty (toim.), Toistemme viholliset? Kirjallisuus kohtaa sisällissodan. Tampere, Vastapaino 2018, $231 \mathrm{~S}$.}

Kukku Melkaksen ja Olli Löytyn toimittama Toistemme viholliset? Kirjallisuus kohtaa sisällissodan käsittelee Suomen vuoden 1918 sisällissodan heijastumia ja kaikuja kirjallisuudessa, sarjakuvassa, kuvataiteessa ja näyttämötaiteessa. Teos koostuu yhdestätoista luvusta, joiden kirjoittajat ovat kirjallisuudentutkijoita, kirjailijoita ja taiteilijoita. Kokonaisuudessaan teos tarkastelee kysymyksiä sodan jättämistä jäljistä, sodasta selviytymisestä, toipumisen mahdollisuudesta sekä yhteisöllisyyden tunteen palauttamisesta sodan jälkeen. Kokoomateoksessa analysoituja teoksia tarkastellaan yrityksinä "ymmärtää traumaattisia kokemuksia ja käsitellä niitä kollektiivisesti." Eräs teoksen keskeisistä teemoista keskittyy yleismaailmalliseen sodan ja väkivallan traumaattisuuteen ja kokemuksellisuuteen sekä näiden kokemusten käsittelyyn kirjallisuudessa ja muissa taiteissa. Toinen teoksen läpäisevä keskeinen teema on jyrkkien, polarisoivien vastakkainasettelujen varassa toimiva viholliskuvien rakentaminen sekä näiden vastakkainasettelujen murtaminen inhimillisen kokemuksen ja ymmärryksen esille tuomisen avulla. Tällöin myös kokonaisia kansakuntia, perheitä ja jopa yksilöiden identiteettejä jakavia vastakkainasetteluja on mahdollista purkaa. Molemmilla teemoilla on kaikupohjaa historian ja nykypäivän tapahtumissa maailmanlaajuisesti.

Melkaksen ja Löytyn kirjoittamassa johdantoluvussa "Miten kirjallisuus kohtaa sodan?" tuodaan oivaltavasti esille se, että ideologiat tuottavat jyrkkiä vastakkainasetteluja pystyäkseen toimimaan, mutta ideologioiden hallitsemassa maailmassa ei ole tilaa horjuville, epäröiville tai vastakkain asetettujen poolien väliin sijoittuville yksilöille tai identiteeteille. Esimerkiksi kaunokirjallisuudessa tai sarjakuva- ja kuvataiteessa voi nousta esille yksilön näkökulma sotaan. Yksilöiden näkökulmat tuovat esille yksilöiden kokemuksen ja maailman, joka ei taivu mustavalkoisiin vastakkainasetteluihin. Kun päästään ihmisen pään sisälle, kokemusten tasolle, kuva muuttuu jyrkän mustavalkoisesta loivemmaksi, harmaan eri sävyiksi. Yksilöt eivät useinkaan ole selkeästi tai yksioikoisesti jonkin ideologian kannattajia, vaan monesti konflikteissa toimimisessa on kyse yksilön selviämiskamppailusta, valintojen tekemisestä pakon edessä ja henkiinjäämisen toivossa. Inhimillisen kokemuksen kautta tarkasteltuna kysymykset meistä ja toisista tai uhrista ja pahantekijästä rakentuvat uusin tavoin tai tavoilla, joita viralliset ideologiset diskurssit eivät tunnista tai suostu tunnustamaan. Tämä ajatus tuodaan vahvasti esille teoksen johdantoluvussa. 
Johdantolukua seuraavat luvut kytkeytyvät tähän keskeiseen kantavaan teemaan eri suunnista, yksilöllisistä ja kollektiivisista näkökulmista.

Ideologisten vastakkainasettelujen murtumista käsittelee osuvasti esimerkiksi Ralf Kaurasen ja Kukku Melkaksen kirjoittama luku "Sodan sävyjä sarjakuvassa". Kaurasen ja Melkaksen analysoima sarjakuva "Kansalaissodan korkeajännitys" käsittelee sodan traumaattisia kuvia vaihtuvista näkökulmista ja vaihtuvien kertojanäänien kertomana. Itsessään traumaattisten tapahtumien kuvat pysyvät samoina, mutta kerrontatapa tuo esille hahmojen näkökulmien ja toiminnan motiivien erot. Samalla sodan molempien osapuolien edustajat näyttäytyvät yhtä aikaa sankarillisina ja pettureina. Sisällissodan moniäänisyyttä korostaa myös Heidi Grönstrandtin kirjoittama luku "Sota kielten sekamelskana". Luku käsittelee sodasta kertomista suomen ja ruotsin kielillä Elmer Diktoniuksen teoksissa Janne Kubik / Janne Kuutio -nimisen hahmon avulla.

Taide on vahva keino murtaa ideologisia, polarisoivia vastakkainasetteluja. Vastakkainasetteluissa ääripäiden välillä ei nähdä vaihtoehtoja, mikä johtaa usein konfliktien puhkeamiseen. Konflikteissa on aina ihmisiä ja yksilöitä, jotka naamioidaan polarisoituneen viholliskuvan taakse. Eri puolella olevan yksilön tai ryhmän demonisointi ja halventaminen eivät ole vain historiaa tai vain sata vuotta sitten käydyn sisällissodan aikaisia tapahtumia. On tärkeä tunnistaa polarisoivien ja vastakkainasettelevien mekanismien ja polarisoinnin mahdollisten seurausten olemassaolo myös nykypäivänä.

Eri yhteiskuntaryhmien välisiä konflikteja ennakoivia asetelmia löytyy myös suomalaisen nyky-yhteiskunnan poliittisista diskursseista ja retoriikasta. Tämän tuo esille Jussi Ojajärvi luvussaan "Kaatuneiden valmistaminen", jossa hän analysoi Arto Salmisen romaaneja. Kahtiajako ja polarisointi voi näkyä myös yksilön sisäisenä kamppailuna. Tästä näkökulmasta tarkastelee Hanna Kuusela Jorma Ollilan ja Tauno Matomäen elämäkertoja luvussa "Vihollinen sisälläni". Elämäkertojen analyysi havainnollistaa, kuinka sadan vuoden takaiset luokkajaot ja käsitykset meistä ja toisista suomalaisessa yhteiskunnassa heijastuvat yksilön elämäntarinaan, minäkuvaan ja identiteetin rakentamiseen. Elämänkerroissa tehdään edelleen jakoa meihin ja toisiin, ja jaolla voidaan nähdä satavuotiset juuret. Petri Tamminen pohtii puolestaan luvussa "Kaikki mitä tapahtuu, tapahtuu minulle" Veijo Meren Vuoden 1918 tapahtumat -teoksen teemoja, joista jokainen voi löytää myös itsensä. Käsittelytavassa korostuvat sodan kaoottisuuden yksilöllinen kokeminen ja traumaattisuuden universaalit piirteet.

Kokoomateos käsittelee sisällissodan traagisia seurauksia ja sodan taakkaa myös yksilöiden ja perheiden näkökulmista monien eri äänien kertomana. Veli-Matti Pynttäri analysoi Toivo Pekkasen romaania Tehtaan varjossa ja Elvi Sinervon Palavankylän seppää. Mervi Kaarninen ja Pirjo Markkola tarkastelevat Sigrid Backmanin sisällissotaromaaneja luvussa "Perhe muuttuu sisällissodan näyttämöksi". Kuvataiteilija Heikki Marila pohtii luvussa "Apokalyptisia kuvia", kuinka hän on teoksissaan hahmottanut ja prosessoinut sisällissodan 
tapahtumia, traumaa ja häpeää. Hanna Suutela puolestaan pohtii Jean D’Arcin hahmoon perustuvan "Pyhä Johanna" -teatteriesityksen merkitystä sisällissodan käsittelyssä 1920-luvun Suomessa. Näytelmässä Eine Laine pystyy Jean D’Arcin hahmon avulla tekemään näkyväksi ja pohtimaan esimerkiksi naisten osallisuutta sodassa ja tuomaan teeman laajemman yleisön pohdittavaksi. Teatterimaailmassa liikkuu myös Heikki Salon kirjoittama luku "Into ja kauhu". Luku kertoo vuoden 1918 sisällissotaan osallistuneen tamperelaisen tyttökaartin kohtaloa käsitelleen musikaalin valmisteluista Tampereen Työväen Teatterissa vuonna 2017. Luvussa "Sotien laajenevat kentät" Olli Löytty tarkastelee kokoomateoksen tematiikkaa avartaen Hassan Blasimin ja Pajtim Statovcin teoksia, jotka käsittelevät Iranin ja Jugoslavian sisällissotia. Teoksissa toistuvat universaalit sodan, menetyksen, kodittomuuden ja pelon teemat.

Toistemme viholliset? on kiinnostava yhdistelmä tieteellisiä artikkeleita ja kaunokirjallisia tekstejä. Se luo ristivalotuksen niihin tapoihin ja tulkintoihin, joilla kirjallisuus ja muut taiteet voivat käsitellä historian yksilöllisiä ja kollektiivisia traumaattisia tapahtumia sekä osallistua esimerkiksi kollektiivisen ja kulttuurisen muistin rakentamiseen. Taiteen keinoin esimerkiksi erilaiset ja väistämättä osittaiset traumaattisten tapahtumien esitykset voivat sijoittua uudelleen osaksi nyky-ymmärrystämme. Traumaattisen historian on näin mahdollista rakentua osittain näkyviin. Teos on myös kiinnostava puheenvuoro siitä, kuinka taiteen keinot voivat dokumentaarisesta kerronnasta poikkeavilla tavoilla käsitellä vaikeiden tapahtumien ja kokemusten monitahoisuutta ja vyyhtimäisyyttä. Traumaattiset tapahtumat ja kokemukset eivät koskaan ole yksiselitteisiä tai yksioikoisesti tulkittavissa olevia. Läpi teoksen nousee pohdittavaksi myös kysymyksiä ideologisten vastakkainasettelujen pysyvyydestä: kuka tarvitsee vastakkainasetteluja ja miksi? Tässäkin mielessä teos on varsin ajankohtainen.

Arvio on kirjoitettu tutkimushankkeessa "Traumaattiset rajat: rajan, järjestyksen ja toiseuden narratiivit" (SA 297533).

\section{Tuulikki Kurki}

